\title{
VIRTUAL TOURISM SEBAGAI ALTERNATIF WISATA SAAT PANDEMI
}

\author{
Rivandy Muhammad $^{(1)}$, Dyah Mutiarin ${ }^{(2) *}$, Janianton Damanik ${ }^{(3)}$ \\ (1)(3)Magister Kajian Pariwisata, Universitas Gajah Mada \\ (2)Magister Ilmu Pemerintahan, Universitas Muhammadiyah Yogyakarta* \\ rivandymuhammad@mail.ugm.ac.id,mutiarin@umy.ac.id, antondmk@ugm.ac.id \\ Submitted : 12 January $2021 \quad$ Revised: 16 March 2021 \\ Accepted : 21 March 2021
}

\begin{abstract}
ABSTRAK
Penelitian ini bertujuan untuk melihat perkembangan mengenai virtual tourism serta bagaimana hal ini diteliti selama 10 tahun terakhir yang dipublikasi oleh Scopus. Penelitian ini membahas bagaimana bentuk pelaksanaan virtual tourism yang dapat dilakukan oleh pelaku usaha pariwisata di masa pandemi Covid-19. Indonesia merupakan salah satu negara yang terdampak virus Covid-19 melaksanakan pembatasan sosial berskala besar untuk mencegah semakin bertambahnya kasus positif di Indonesia, akibatnya berbagai sektor industri terkena dampaknya salah satunya, yakni pariwisata. Menurunnya kunjungan wisatawan, pemutusan hubungan kerja, pelaku usaha pariwisata yang gulung tikar terjadi akibat meluasnya virus Covid-19, serta menurunnya kunjungan wisatawan ke objek dan daya tarik wisata. Penelitian ini menggunakan analisis bibliometrik dengan alat analisis menggunakan aplikasi Vosviewer 1.6.16.
\end{abstract}

Kata Kunci : Virtual tourism, Destinasi, Covid-19

\section{VIRTUAL TOUR AS AN ALTERNATIVE IN PANDEMIC COVID-19}

\begin{abstract}
The Covid-19 pandemic that occurred in almost all countries led to changes in people's behavior which required them to stay at home because there was an increase in confirmed positive cases so that some countries implemented lockdown policies. Indonesia is one of the countries affected by the Covid-19 virus implementing large-scale social restrictions to prevent the increasing number of positive cases in Indonesia, as a result of which various industrial sectors are affected, one of which is tourism. The decline in tourist visits, layoffs of employment, business actors who went bankrupt occurred due to the spread of the Covid-19 virus, and the decline in tourist visits to tourist objects and attractions. This study uses bibliometric analysis with analysis tools using the Vosviewer 1.6 application. This research discusses how the form of virtual tourism implementation that can be carried out by tourism businesses during the Covid-19 pandemic, as well as how virtual tourism has been researched over the last 10 years published by Scopus.
\end{abstract}

Keywords: Virtual tourism, Destination, Covid-19 


\section{PENDAHULUAN}

Terhitung bulan Maret 2020 Coronavirus disease 19 atau yang lebih dikenal dengan Covid-19 mulai menyebar di seluruh dunia, seluruh negara melakukan pencegahan dan antisipasi meluasnya penyebaran Covid-19 dengan melakukan pembatasan pergerakan penduduk baik yang akan masuk maupun keluar dari negaranya. Indonesia sebagai salah satu negara di Asia yang terdampak Covid-19 memutuskan melakukan strategi pembatasan fisik dan pembatasan sosial, dimana pembatasan ini dinilai sebagai salah satu langkah yang efektif dalam rangka menghentikan penyebaran virus Covid-19. Semakin bertambahnya kasus terjangkit Covid-19, pemerintah daerah semakin gencar melakukan sosialisasi kepada masyarakat agar tidak melakukan kegiatan di luar rumah, penyelenggaraan ibadah di rumah-rumah ibadah, serta perjalanan baik dalam maupun luar kota. Pandemi Covid-19 ini tentunya berdampak kepada seluruh sektor yang ada di Negara Indonesia, salah satunya ialah sektor pariwisata.

Pariwisata merupakan sektor yang terdampak akibat meluasnya Covid-19, banyak karyawan hotel maupun karyawan di destinasi pariwisata tidak bisa bekerja sebagaimana mestinya untuk mencegah meluasnya virus ini (Nuruddin et al 2020:580), Dengan diberlakukannya pembatasan sosial berskala besar (PSBB) sebagai upaya meredam penyebaran Covid-19 membuat pergerakan masyarakat menjadi terbatas termasuk masyarakat lokal yang ingin melakukan perjalanan wisata, bagi masyarakat yang ingin berwisata diharuskan menjalani swab test antigen untuk memastikan kondisi fisik dalam keadaan sehat dan tetap menjalankan protokol kesehatan yang telah ditetapkan pemerintah Indonesia baik saat berwisata maupun saat kembali ke daerah semula, bagi wisatawan yang masih ragu untuk berwisata tentunya mengalami kejenuhan karena berdiam diri dengan waktu yang cukup lama di rumah masingmasing, berwisata merupakan salah satu upaya untuk menghilangkan kejenuhan di rumah (Kalebos, 2016:490).

Berdasarkan fenomena diatas, tentunya diperlukan alternatif berwisata dimana wisatawan tetap bisa menikmati keindahan daerah tujuan wisata dengan tetap memperhatikan kesehatan ataupun keselamatan bersama. Salah satu konsep berwisata yang dapat dilakukan adalah Virtual tour (Riesa \& Haries, 2020:2). Virtual tour merupakan salah satu bentuk berwisata dimana wisatawan dapat menikmati objek wisata tanpa harus mengunjungi objek wisata secara langsung. Virtual tour bisa menjadi titik awal sebagai wisata alternatif selama pandemi Covid-19 hingga setelah pandemi ini berakhir.

Berdasarkan uraian pendahulan diatas, rumusan masalah pada penelitian ini, diantaranya adalah bagaimana perkembangan penelitian mengenai virtual tourism dan bagaimana bentuk virtual tourism yang dapat dilakukan untuk menarik wisatawan.

\section{TINJAUAN PUSTAKA Virtual Tourism}

Virtual tourism menawarkan pengalaman yang tanpa mengambil risiko dan merusak sebuah destinasi wisata dan memungkinkan seluruh wisatawan bisa melihat daya tarik wisata dengan kapasitas daerah tujuan wisata yang sedikit.

$$
\text { Waraney et al. (2017:2). }
$$
menambahkan virtual tourism merupakan teknologi yang memungkinkan wisatawan melihat sebuah daya tarik wisata dalam bentuk gambar dan video sehingga bisa membayangkan sebuah destinasi dengan baik. Virtual tourism dapat dijadikan sebuah media yang bisa menghadirkan dan menghidupkan imajinasi bagi para penggunanya. Sehingga penggunanya seolah-olah mengalami dan merasakan keadaan yang sesungguhnya Suhendar \& Fernando, (2016). 
Daud et al., (2016) menambahkan virtual tour merupakan sebuah simulasi dari sebuah lokasi yang terdiri dari rentetan gambar. Rentetan gambar tersebut akan digabungkan untuk menghasilkan foto panorama 360 derajat. Virtual tour sendiri biasanya digunakan untuk memberi pengalaman pernah berada di suatu tempat hanya dengan melihat layar monitor. Penyajian virtual tour dapat dilakukan dengan cara memanfaatkan gambar ataupun video. Selain itu, dapat menggunakan model tiga dimensi. Untuk penyajian dengan menggunakan gambar, dapat digunakan foto panorama. Pemilihan jenis foto panorama juga mempengaruhi hasil virtual tour yang dihasilkan. Menurut Valentina \& Handjojo, (2013), Untuk panorama jenis cylindrical, bagian vertikalnya hanya dapat menangkap tidak lebih dari 180 derajat sedangkan jenis spherical, memungkinkan untuk melihat ke atas dan ke bawah (Daud et al.2016).

Virtual Tour adalah sebuah simulasi dari suatu lingkungan nyata yang ditampilkan secara online, biasanya terdiri dari kumpulan foto-foto panorama, kumpulan gambar yang terhubung oleh hyperlink, ataupun video dan virtual model dari lokasi yang sebenarnya serta dapat menggunakan unsur-unsur multimedia lainnya,seperti efek suara, music, narasi, dan tulisan (Valentina \& Handjojo, 2013).

\section{Bentuk Virtual Tourism}

Studi yang dilakukan oleh (Riesa \& Haries, 2020:4) menjabarkan bahwa virtual tourism dapat dilakukan melalui enam bentuk, yaitu:

\section{a. Gambar atau foto}

Gambar atau foto merupakan media visual. Dimana media ini memiliki fungsi untuk menyalurkan pesan dari penerima sumber ke penerima pesan. Pesan tersebut akan disampaikan ke dalam simbol-simbol komunikasi visual, simbol tersebut perlu dipahami dengan benar, artinya agar proses penyampaian pesan dapat berhasil dengan baik dan tidak menimbulkan kesalahan (Haryanti, 2018).

\section{b. Virtual Reality Photography}

VRP adalah sebuah Teknik foto panorama yang menyajikan suasana dengan pemandangan secara spherical view, Yuliana dan Listianto (2017). Menurut Dio, Safriadi, dan Sukamto (2019), foto panorama merupakan gabungan dari beberapa foto dengan tujuan untuk mendapatkan foto dengan sudut pandang yang lebar dan mencakupi pemandangan yang luas. Foto panorama bahkan mampu mempresentasikan objek hingga $360^{\circ}$.

\section{c. Video}

Video didefinisikan sebagai potongan gambar tunggal yang disebut frames. Hasil pengolahan beberapa gambar yang membuat ilusi gambar bergerak karena otak tidak menangkap gambar secara individual, Waraney, Tulenen, dan Sinsuw (2017.p2). Video-video ini dapat diakses melalui televisi, komputer, web, ataupun melalui smartphone.

\section{d. Video $360^{\circ}$}

Menurut Brown et all (2016), video 360 derajat adalah salah satu bentuk dari Virtual Reality dimana sudut pandang pengguna dapat berbentuk spherical (bulat) atau hampir bulat dimana pusat video berada di bagian tengah. Video 360 derajat direkam dengan kamera yang bersifat omnidirectional atau melalui beberapa kamera yang dapat merekam sekeliling dan masing-masing video dijahit untuk membentuk sebuah video 360 derajat. Video ini dapat diakses dengan menggunakan Google Cardboard. Alat ini dapat memberikan pengalaman virtual reality kepada penggunanya dengan bantuan smartphone dimana pengguna dapat merasakan pengalaman, seperti benar-benar berada di lingkungan tersebut.

\section{e. Interactive Video $360^{\circ}$}

Video $360^{\circ}$ interaktif merupakan pengembangan dari video $360^{\circ}$ yang sudah ditingkatkan kualitasnya, Choi et all (2018). Kualitas yang ditambahkan dapat 
Rivandy Muhammad, Dyah Mutiarin, Janianton Damanik: Virtual Tourism sebagai Alternatif Wisata Saat Pandemi

berupa menambahkan URL (Uniform Resource Locator) ke dalamnya, mengubah adegan melalui tombol klik dan menambahkan efek khusus sehingga tidak terlihat perbedaan dalam gabungan videovideo tersebut. Meskipun begitu, video $360^{\circ}$ interaktif ini belumlah digunakan secara luas.

\section{f. Virtual Reality}

Virtual reality adalah teknologi yang membuat pengguna dapat berinteraksi dengan suatu lingkungan yang disimulasikan oleh komputer (computer simulated environment), suatu lingkungan sebenarnya yang ditiru atau benar-benar suatu lingkungan yang hanya ada dalam imaginasi.

Lingkungan realitas maya terkini umumnya menyajikan pengalaman visual, yang ditampilkan pada sebuah layar komputer atau melalui sebuah penampil stereokopik tetapi beberapa simulasi mengikutsertakan tambahan informasi hasil penginderaan, seperti suara melalui speaker atau headphone (Sihite, et., al, 2013). Asfari, et., al (2012) menambahkan Virtual Reality (VR) merupakan ruang digital dimana seluruh gerakan pengguna dapat diketahui atau dilacak dan mengetahui gambaran sekitarnya.

Hasil yang didapat disusun dan ditampilkan ke indra manusia sesuai dengan gerakan-gerakan yang dilakukan. Studi yang dilakukan (Kharismajati et al., 2020) mengenai virtual tour di Kabupaten Purbalingga, memperoleh temuan bahwa virtual tour dapat dilakukan melalui aplikasi smartphone dan memperoleh uji kelayakan sebesar $88 \%$

\section{METODE PENELITIAN}

Penelitian ini menggunakan pendekatan analisis bibliometric mapping merupakan bagian dari bibliometri yang bertujuan untuk menghasilkan representasi visual atas hubungan-hubungan yang ada diantara unit-unit yang dikaji.

Unit kajian bisa berupa dokumen, pengarang, atau kata kunci sedangkan relasi antar unit ini bisa berupa citations, co-citations, co-authorship, atau cooccurrences of keywords (Heersmink et al, 2010) dalam (Setyowati, 2020).

Adapun alat analisis yang digunakan adalah Vosviewer versi 1.6.16 untuk mengetahui perkembangan penelitian mengenai virtual tourism dan studi literatur untuk mengetahui apa saja bentuk virtual tourism yang dapat dilakukan pada masa pandemi Covid-19.

\section{HASIL DAN PEMBAHASAN}

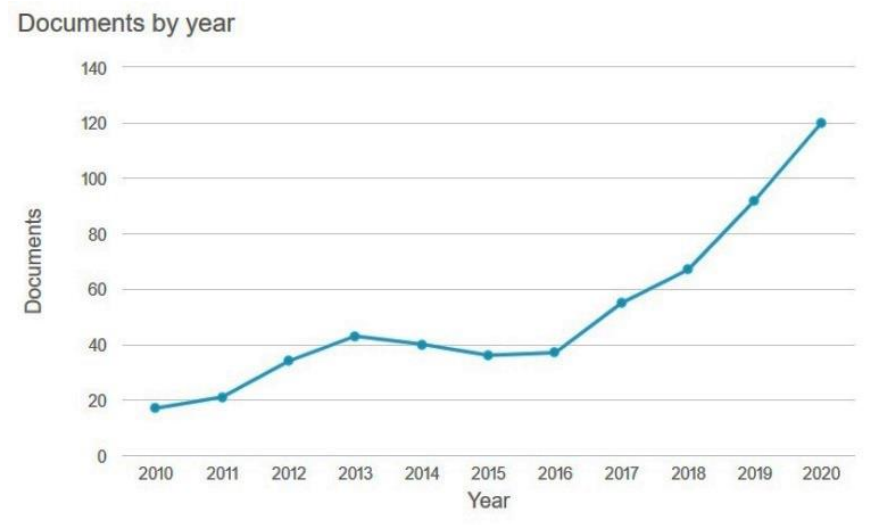

Gambar 1 Jumlah Penelitian Mengenai Virtual Tourism Tahun 2010-2020

Sumber: Hasil olah data Scopus menggunakan Vosviewer 1.6.16, 2020

Berdasarkan Gambar 1 diketahui selama sepuluh tahun terakhir, penelitian mengenai virtual tourism terjadi peningkatan dan penurunan, tahun 2010 tercatat terdapat 19 penelitian mengenai virtual tourism yang terpublikasi oleh Scopus, tahun 2020 tercatat jumlah penelitian yang terpublish oleh Scopus sebanyak 120.

Berdasarkan Gambar 1 dapat disimpulkan bahwa kajian mengenai wisata berbasis digital semakin meningkat tiap tahunnya, diharapkan menyumbangkan ide dan pikiran baru bagi pelaku usaha pariwisata bahwa saat ini wisata alternatif dalam bentuk virtual dapat dilakukan, mengingat mayoritas negara didunia mengalami pandemi akibat virus Covid-19. 
Pada hasil bibliometric penelitian ini diketahui bahwa virtual tourism akan memberikan dampak kepada beberapa sektor diantaranya culture, behavior, perception, destination, dan satisfaction. Dimana dari beberapa sektor yang muncul pada gambar 2 menjelaskan bahwa hubungan antara virtual tourism dengan beberapa sektor memiliki dampak yang besar dan akan memberikan persepsi yang

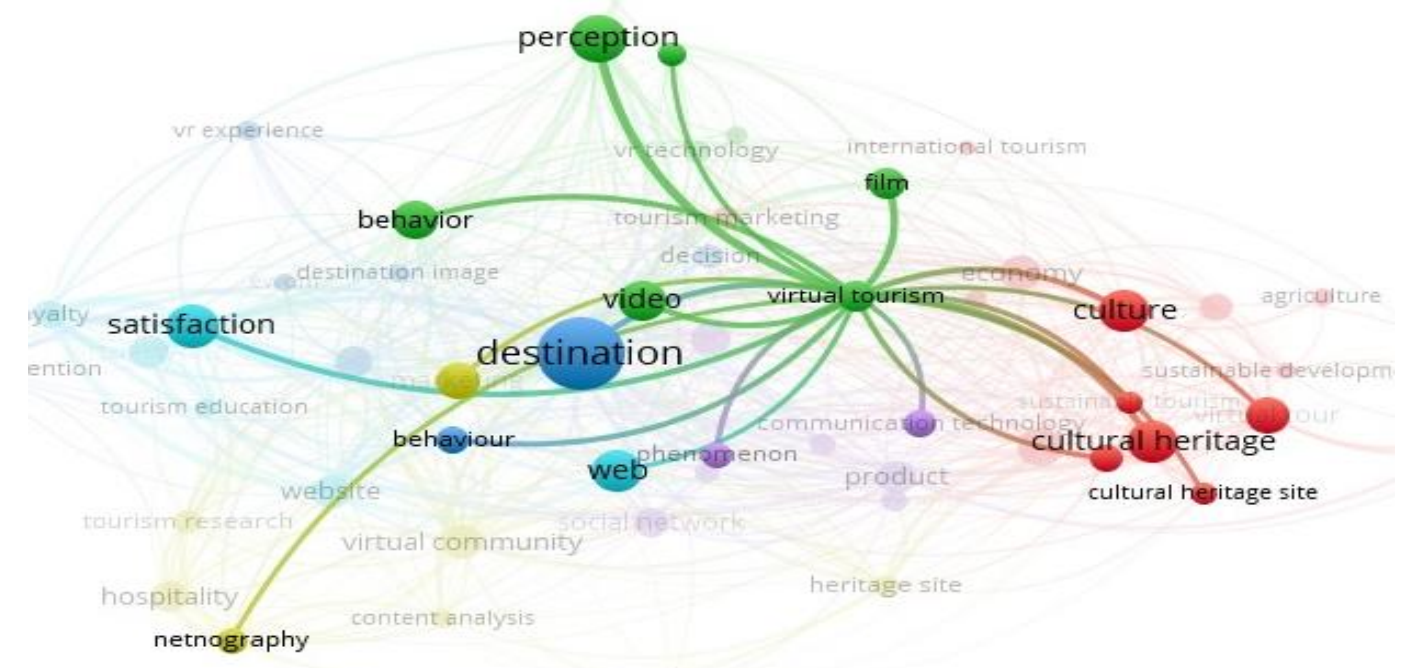

Gambar 2 Jaringan Virtual Tourism

Sumber: Hasil olah data Scopus menggunakan Vosviewer 1.6.16, 2020

Berdasarkan Gambar 2 yang merupakan jaringan virtual tourism, selama sepuluh tahun terakhir tercatat terdapat penelitian dengan total link strength sebanyak 57 buah penelitian, dapat disimpulkan bahwa virtual tourism terus dikaji oleh para peneliti dengan sudut pandang yang beragam dimulai dari detinasi, perilaku, dan pemasaran hingga pariwisata berkelanjutan. hasil penelitian ini diketahui bahwa virtual tourism akan memberikan dampak kepada beberapa sektor diantaranya culture, behavior, perception, destination, dan satisfaction.

\section{KESIMPULAN}

Berdasarkan hasil pengolahan data Scopus menggunakan software Vosviewer 1.6.16 diketahui selama sepuluh tahun

Menggunakan teknologi, virtual tourism menempatkan pengguna ke dalam muncul dari masyarakat bagaimana virtual tourism akan meningkatkan kepuasan terhadap masyarakat di tengah pandemi. 
Rivandy Muhammad, Dyah Mutiarin, Janianton Damanik: Virtual Tourism sebagai Alternatif Wisata Saat Pandemi

serta meningkatkan tampilan, penangkapan, dan analisis data virtual secara signifikan. Melalui virtual tourism, wisatawan dapat mencicipi perpaduan gambar, musik, video, tampilan peta, dan

\section{DAFTAR PUSTAKA}

Asfari, U., Setiawan, B., \& Sani, N. A. (2012). Pembuatan aplikasi tata ruang tiga dimensi gedung serba guna menggunakan teknologi virtual reality [studi kasus: Graha ITS Surabaya]. Jurnal Teknik ITS, 1(1), A540-A544.

Brown, A., \& Green, T. (2016). Virtual reality: Low-cost tools and resources for the classroom. TechTrends, 60(5), 517-519.

Choi, I., Ofek, E., Benko, H., Sinclair, M., \& Holz, C. (2018, April). Claw: A multifunctional handheld haptic controller for grasping, touching, and triggering in virtual reality. In Proceedings of the 2018 CHI Conference on Human Factors in Computing Systems (pp. 1-13).

Daud, F. R., Tulenan, V., \& Najoan, X. B. N. (2016). Virtual Tour Panorama 360 Derajat Kampus Universitas Sam Ratulangi Manado. Jurnal Teknik Informatika, 8(1). https://doi.org/10.35793/jti.8.1.2016.1 3173

Dio, D., Safriadi, N., \& Sukamto, A. S. Rancang Bangun Aplikasi Virtual Tour Lokasi Rekreasi dan Hiburan Keluarga di Pontianak. JUSTIN (Jurnal Sistem dan Teknologi Informasi), 7(1), 1-6.

Haryanti, R. H. (2018, February). People with Disability in Vocational High Schools: between School and Work. In IOP Conference Series: Materials Science and Engineering (Vol. 306, No. 1, p. 012105). IOP Publishing.

Kalebos, F. (2016). Faktor-Faktor Yang Mempengaruhi Kepuasan Wisatawan Yang Berkunjung Ke Daerah Wisata Kepulauan. Jurnal Riset Bisnis Dan Manajem, 4, 489-502. narasi dalam satu pengalaman terintegrasi (Rastati, 2020).

Kharismajati, G., Umar, R., \& Sunardi, S. (2020). Inovasi Promosi Obyek Wisata Purbalingga Menggunakan Teknologi Virtual Reality 360 Panorama Berbasis Android. JIKO (Jurnal Informatika Dan Komputer), 3(2), 62-68. https://doi.org/10.33387/jiko.v3i2.175 6

Listianto, K. F., Fauzi, R. I., Irviani, R., Kasmi, K., \& Garaika, G. (2017). Aplikasi E-Commerce Berbasis Web Mobile Pada Industri Konveksi Seragam Drumband Di Pekon Klaten Gadingrejo Kabupaten Pringsewu. $J$. TAM (Technol. Accept. Model), 8(2), 146-152.

Nuruddin, Wirawan, P. E., Pujiastuti, S., \& Sri Astuti, N. N. (2020). Strategi Bertahan Hotel di Bali Saat Pandemi Covid-19. Jurnal Kajian Bali (Journal of Bali Studies), 10(2), 579. https://doi.org/10.24843/jkb.2020.v10 .i02.p11

Rastati, R. (2020). Virtual Tour: Tourism in the Time of Corona. 510(Icosaps), 489-494.

Riesa, R. M., \& Haries, A. (2020). Virtual tourism dalam literature review. 01(1), 1-6.

Setyowati, L. (2020). Pengenalan Bibliometric Mapping sebagai Bentuk Pengembangan Layanan Research Support Services Perguruan Tinggi. JPUA: Jurnal Perpustakaan Universitas Airlangga: Media Informasi Dan Komunikasi Kepustakawanan, $10(1), \quad 1$. https://doi.org/10.20473/jpua.v10i1.2 020.1-9

Sihite, B., Samopa, F., \& Sani, N. A. (2013). Pembuatan Aplikasi 3D 
Rivandy Muhammad, Dyah Mutiarin, Janianton Damanik: Virtual Tourism sebagai Alternatif Wisata Saat Pandemi

Viewer Mobile dengan Menggunakan Teknologi Virtual Reality (Studi Kasus: Perobekan Bendera Belanda di Hotel Majapahit). Jurnal Teknik ITS, 2(2), A397-A400.

Suhendar, A., \& Fernando, A. (2016). Aplikasi Virtual tour Berbasis Multimedia Interaktif Menggunakan Autodesk 3Ds Max. ProTekInfo (Pengembangan Riset dan Observasi Teknik Informatika), 3, 30-35.

Umafagur, F., Sentinuwo, S. R., \& Sugiarso, B. A. (2016). Implementasi Virtual Tour Sebagai Media Informasi Daerah (Studi Kasus : Kota Manado). Jurnal Teknik Informatika, 9(1). https://doi.org/10.35793/jti.9.1.2016.1 3456

Valentina, F., \& Handjojo. (2013). Perancangan Dan Implementasi Aplikasi Content Management System Dengan Format Virtual Online Tour. 1(2), 1-6.

Waraney, S. P. F., Tulenan, V., \& Sinsuw, A. A. E. (2017). Pengembangan Virtual Tour Potensi Wisata Baru Di Sulawesi Utara Menggunakan Teknologi Video 360 Derajat. Jurnal Teknik Informatika, 12(1), 1-8. https://doi.org/10.35793/jti.12.1.2017. 17786. 
60 - JITHOR Vol.4, No.1, April 2021 - eISSN : 2654-4687 pISSN : 2654-3894 